\title{
Ervaringen uit de collegezaal
}

\section{Een verslag van de discussie over rechtssociologisch onderwijs in Nederland $^{*}$}

Reyer Baas

\section{$1 \quad$ Inleiding}

Rechtssociologen uit het Nederlandse taalgebied treffen elkaar minstens één keer per jaar. Op de agenda staan onder andere lezingen, onderzoekspresentaties met referenties, discussiepanels over actueel onderzoek en author-meets-readerssessies. Opmerkelijk genoeg ontbreekt vaak een gedachtewisseling over het onderwijs, terwijl het merendeel van de onderzoekers ook betrokken is bij het onderwijs in de rechtssociologie. Deze omissie was voor de rechtssociologen van de Radboud Universiteit Nijmegen reden om met vakgenoten van de andere rechtenfaculteiten op 28 maart 2014 ervaringen en ideeën uit te wisselen over het rechtssociologisch onderwijs in Nederland.

Aan discussiestof was zeker geen gebrek. Zo is het goed te weten welke vraagstukken, theorieën en literatuur elders worden behandeld. Hoe is de aansluiting op het juridische onderwijs? Doen de studenten zelf onderzoek, schrijven ze essays, houden ze presentaties? En bovenal: zijn we tevreden over ons onderwijs en wat vinden de studenten ervan?

\section{Zes persoonlijke verhalen}

De aftrap werd gedaan zeven rechtssociologen. Zij hielden een voordracht over het rechtssociologisch onderwijs aan hun universiteit. Nienke Doornbos (UvA) vertelde dat in Amsterdam het recht sterk vanuit de praktijk wordt benaderd. Studenten leren ficties te relativeren en de effectiviteit van het recht te begrijpen. Sinds 2013 volgen derdejaars rechtenstudenten een cursus over de interactie tussen recht en menselijk gedrag. Deze cursus is thematisch ingericht. Zo wordt de ene week verteld over het gedrag van de mens als groepsdier en hoe deze kennis in het recht en in de praktijk wordt benut. De andere week gaat het over cognitieve beperkingen, die ertoe leiden dat beslissingen niet altijd bewust en weloverwogen worden genomen. Weer een andere keer wordt de mens beschouwd vanuit de neurowetenschappen: heeft de mens een vrije wil en welke gevolgen heeft het antwoord op deze vraag voor het recht?

* De auteur dankt Miek Laemers en Anoeshka Gehring voor hun ondersteuning bij de verslaglegging. 
Marc Hertogh (RUG) lichtte de vakken toe over de sociaalwetenschappelijke bestudering van het recht in Groningen. Zo vertellen buitenlandse studenten die het vak Anthropology of law volgen over de verhouding tussen recht en cultuur in hun eigen land. In het vak Recht en sociaalwetenschappelijk onderzoek maken studenten kennis met onderzoeksmethoden uit onder andere de economie, sociologie en politicologie. Hertogh legde ook een vijftal dilemma's voor waarvoor docenten zich geregeld gesteld zien: Willen we 'kort en breed' onderwijs of juist 'lang en diep'? Moeten we onderwijzen in wat juristen willen horen of in wat juristen móéten horen? Dient rechtssociologie een zelfstandig vak te blijven of ligt integratie met juridische vakken meer voor de hand? Laten we studenten klassieke stukken lezen of leggen we hun actueel onderzoek voor? Moeten we studenten vooral veel vertellen of hen daarentegen juist meer zelf laten doen?

Wibo van Rossum (UU) wees erop dat het vak rechtssociologie leert om kritisch te zijn op vanzelfsprekendheden en aannames van juristen en rechtssociologen. In het onderwijs komen ideeën van wegbereiders aan bod, zoals Weber, Marx, Durkheim, de Frankfurter Schule, Habermas, Foucault, Mead en Blumer. Studenten analyseren actuele artikelen op vraagstelling, methoden, empirische resultaten en inzichten. De voorgeschreven literatuur is jarenlang Recht van onderop geweest; thans wordt gezocht naar nieuwe literatuur. Studenten schrijven ook een paper, waarvoor ze twee interviews afnemen, en houden daarover een presentatie.

Huub Spoormans (OU) vertelde dat studenten aan de Open Universiteit maar liefst vier metajuridische bachelorvakken volgen: rechtssociologie, rechtsfilosofie, rechtsgeschiedenis en academische vaardigheden. Rechtssociologie biedt conceptueel inzicht in de werking van het recht in de samenleving. Het vak wordt momenteel herzien en de OU zoekt daartoe samenwerking met anderen. In de master bestaat sinds kort de cursus Recht in multidisciplinair perspectief, waarin de verhouding tussen juridisch en sociaalwetenschappelijk denken wordt bestudeerd. De menskracht om de cursussen te ontwikkelen en uit te voeren is echter beperkt. Alleen door nauw samen te werken met docenten van andere opleidingen is het mogelijk deze aan te blijven bieden.

Roel Pieterman (EUR) vertelde dat het onderwijs in Rotterdam sinds 2013 probleemgestuurd is. Studenten gaan daardoor in kleine groepen zelf met de stof aan de slag, terwijl de docent een begeleidende rol heeft. Studenten bereiden zich mede voor door klassieke teksten te lezen: van Durkheim over het recht als functioneel systeem; van Marx over het recht bezien vanuit het conflictperspectief; en van Weber over rationalisatie en bureaucratie. Studenten doen ook zelf onderzoek: zij interviewen bijvoorbeeld aan de hand van de trits naming-blamingclaiming een persoonlijke kennis over een conflictsituatie die deze heeft meegemaakt. Pieterman wees er tevens op dat het rechtenonderwijs steeds positiefrechtelijker wordt. Hij sprak de vrees uit dat het rechtssociologisch onderwijs overbodig wordt verklaard als andere vakken ook een empirische component inbouwen. In die zin is er sprake van een paradox: enerzijds hebben rechtssociologen zelf veel te vertellen, anderzijds nemen anderen de rechtssociologie over. 
Adriaan Bedner en Marjolein Odekerken (UL) merkten op dat in Leiden rechtssociologie, anders dan rechtsfilosofie, geen verplicht vak is. Toch voorziet het metajuridische vak Law \& culture in een behoefte: het is populair bij buitenlandse studenten en ook geschikt en bedoeld voor niet-juristen. Diverse docenten behandelen vragen als: Is recht een product van cultuur? Is cultuur te beïnvloeden met het recht? Hoe gaat het recht met culturele diversiteit om? Moet het strafrecht bijvoorbeeld rekening houden met de culturele achtergrond van daders? De insteek is interactief: er is veel ruimte voor discussie. Studenten schrijven een essay, bijvoorbeeld over eerwraak, en houden een presentatie.

\section{Hoe breed geven we rechtssociologisch onderwijs?}

Het vervolg van de discussie werd gekanaliseerd aan de hand van vier vragen. Ten eerste: hoe breed geven we rechtssociologisch onderwijs? In reactie daarop stelden meerdere deelnemers dat rechtssociologie een imagoprobleem heeft. Studenten zijn niet zelden sceptisch over het nut van rechtssociologisch onderwijs. Doornbos merkte daarbij op dat het rechtssociologisch onderzoek tegenwoordig minder verheffend wordt gevonden dan in de jaren zeventig. Thans is het sociaalpsychologische en cognitieve onderzoek van grotere betekenis. Onderwijs in de bredere context van recht en gedrag biedt ruimte om meer te behandelen dan alleen rechtssociologische thema's, en kan daardoor studenten meer aanspreken. Diverse deelnemers suggereerden ook dat toepassing van de andere sociale wetenschappen tot uitdrukking moet worden gebracht in de naam van het vak. Hier staat tegenover dat de keuze uit rechtssociologische en metajuridische theorieën en thema's zeer groot is. De verleiding bestaat om te veel te behandelen. We dienen daarvoor te waken: we moeten niet de pretentie hebben studenten alles te kunnen of willen leren, maar laten zien dat de rechtssociologie bijdraagt aan begrip van de werking van het recht.

\section{Laten we studenten zelf onderzoek doen?}

Onderwijs en onderzoek versterken elkaar. Kennismaking met onderzoek is voor veel studenten een eyeopener, wat de reflectie op het recht en de rechtssociologie ten goede komt, zo luidde de consensus. Is het ook zinvol om studenten zelf een onderzoek te laten uitvoeren? Ja, vonden bijna alle deelnemers. Het is belangrijk om studenten in de praktijk te laten 'proeven' aan onderzoek, maar er zijn diverse manieren waarop dat kan gebeuren. Zo interviewen Groningse eerstejaars studenten horecaondernemers over het rookverbod in cafés en restaurants. In Rotterdam maken studenten een opdracht die vervolgens door middel van peer review met ouderejaars in werkgroepen wordt besproken. In Nijmegen voeren studenten een leeronderzoek uit over een zelfgekozen onderwerp, bijvoorbeeld naar de invloed van Greenpeace of Shell op het Europees milieubeleid. 


\section{Hoe sluiten we aan bij het juridisch onderwijs?}

De deelnemers waren het erover eens dat het doel van rechtssociologie niet is om studenten op te leiden tot rechtssocioloog, maar om hen op het recht te laten reflecteren op basis van sociaalwetenschappelijke inzichten. Bijna alle deelnemers vonden ook dat rechtssociologie moet aansluiten op het positiefrechtelijke onderwijs. Dat kan door casussen uit een van de rechtsgebieden te bespreken, zeker wanneer deze aansluiten op de 'kernthema's' van een faculteit. Populair is om te reflecteren op maatschappelijke vraagstukken die stof hebben doen opwaaien, zoals het alcoholverbod voor tieners, de ontdekking van het kartel in de bouwwereld of de opheffing van het bordeelverbod. De achtergronden van een rechtszaak behandelen, zoals de strafzaak tegen Lucia de Berk, biedt eveneens aanknopingspunten. Er zijn tevens kansen op het gebied van onderzoek. Gezamenlijke begeleiding van een promovendus of scriptiestudent is zinvol. In Nijmegen bestaat het plan om met collega's van de positiefrechtelijke vakken ideeën voor gezamenlijke projecten te genereren. Zo krijgen de collega's beter inzicht in de meerwaarde van rechtssociologie, en de rechtssociologen meer zicht op de thema's van het juridisch onderwijs.

\section{Hoe doceren we rechtssociologische theorieën?}

Een mogelijk gevolg van de keuze om rechtssociologisch onderwijs 'breed en kort' te doceren, is dat studenten niet leren om theorieën toe te passen. Dat is jammer, zeker omdat theorievorming en -toepassing elders in de rechtenopleiding nauwelijks een plaats hebben, terwijl ze een noodzakelijk onderdeel zijn van de academische vorming. De kennismaking met theorieën is echter niet voldoende: studenten moeten vooral ook het nut en de bruikbaarheid ervan leren inzien. Als studenten beseffen dat theorieën handige instrumenten zijn om actuele maatschappelijke en juridische kwesties te doorgronden, vergroot dit het begrip van en het plezier in de rechtssociologie. Maar hoe doceren we theorieën? Een mogelijkheid is om actuele vraagstukken als uitgangspunt te nemen en daar een passende theorie bij te gebruiken. Een alternatieve aanpak is om beginselen als vertrouwen of autonomie als fundament te gebruiken, om deze vervolgens in de actualiteit te plaatsen. Dit levert casusposities op die kunnen worden verklaard door ze in een theoretisch kader te zetten.

\section{Conclusie}

De rechtssociologen waren eensgezind over een aantal fundamentele onderwijskwesties. Zij concludeerden dat het zinvol is om studenten zelf onderzoek te laten doen, al is het aantal onderwijsuren daarvoor niet altijd toereikend. Docenten dienen studenten ook het belang van theoretische benaderingen bij te brengen en hen kennis te laten maken met belangrijke rechtssociologische theorieën. De meeste deelnemers vonden ook dat rechtssociologie moet aansluiten op het juridisch onderwijs. Daardoor kan het voornaamste doel - namelijk om studenten op 
het recht te laten reflecteren met behulp van sociaalwetenschappelijke inzichten - waarschijnlijk het beste worden gerealiseerd. Minder eensgezindheid bestond er over de vraag hoe breed het rechtssociologisch onderwijs idealiter is. Daarnaast meenden diverse deelnemers dat het huidige rechtssociologisch onderwijs studenten onvoldoende aanspreekt. Sommigen vonden dat het onderwijs daarom vernieuwender zou moeten zijn. De deelnemers opperden nog meer ideeën. Docenten kunnen bijvoorbeeld onderwijsmateriaal en -ideeën uitwisselen of op de website van de vsr plaatsen. Recht der Werkelijkheid kan een onderwijs-special uitbrengen. Een nog te ontwikkelen 'canon van de rechtssociologie' kan behulpzaam zijn bij de keuze uit thema's en theorieën in het onderwijs.

Met één middag discussiëren is een onderwijsdebat natuurlijk nog lang niet ten einde. Maar de bijeenkomst bood wel stof tot nadenken en een aanzet tot verdere discussie. Wordt vast vervolgd! 